\title{
Association between phage types and antimicrobial resistance among bovine Staphylococcus aureus from 10 countries
}

Vintov, J.; Aarestrup, Frank Møller; Zinn, C. E.; Olsen, J. E.

Published in:

Veterinary Microbiology

Link to article, DOI:

10.1016/S0378-1135(03)00156-1

Publication date:

2003

Document Version

Publisher's PDF, also known as Version of record

Link back to DTU Orbit

Citation (APA):

Vintov, J., Aarestrup, F. M., Zinn, C. E., \& Olsen, J. E. (2003). Association between phage types and antimicrobial resistance among bovine Staphylococcus aureus from 10 countries. Veterinary Microbiology, 95(12), 133-147. https://doi.org/10.1016/S0378-1135(03)00156-1

\section{General rights}

Copyright and moral rights for the publications made accessible in the public portal are retained by the authors and/or other copyright owners and it is a condition of accessing publications that users recognise and abide by the legal requirements associated with these rights.

- Users may download and print one copy of any publication from the public portal for the purpose of private study or research.

- You may not further distribute the material or use it for any profit-making activity or commercial gain

- You may freely distribute the URL identifying the publication in the public portal 


\title{
Association between phage types and antimicrobial resistance among bovine Staphylococcus aureus from 10 countries
}

\author{
Jan Vintov ${ }^{\mathrm{a}, \mathrm{b}}$, Frank Møller Aarestrup ${ }^{\mathrm{a}, *}$, Christina Elsberg Zinn ${ }^{\mathrm{c}}$, \\ John Elmerdahl Olsen ${ }^{b}$ \\ a Danish Veterinary Institute, Bülowsvej 27, DK-1790 Copenhagen, Denmark \\ ${ }^{\mathrm{b}}$ Department of Veterinary Microbiology, Stigbøjlen 4, The Royal Veterinary and Agricultural University, \\ DK-1870 Frederiksberg, Denmark \\ c Statens Serum Institut, DK-2300 Copenhagen S, Denmark
}

Received 11 October 2002; received in revised form 11 April 2003; accepted 24 April 2003

\begin{abstract}
This study was conducted to investigate the diversity of phage types and associations between penicillin resistance and phage types among 815 Staphylococcus aureus isolates from bovine mastitis in nine European countries and USA. All isolates were examined for susceptibility to antimicrobial agents and characterised by phage typing. Penicillin resistance was found among strains from all countries with an average occurrence of $32.4 \%$ (2-71.4\%). A total of $76 \%$ of isolates were identifiable by phage typing and 144 different phage types were observed. The most predominant types were phage type 29 (11\% of the 815 isolates), phage type $52(5 \%)$, and phage type $80(5 \%)$. Phage type 95 and 29/52/52A/80 were both distributed within seven countries. In the countries with the highest occurrence of penicillin resistance a reduced diversity of phage types and phage groups was observed. Phage group III was significantly associated with penicillin resistance in contrast to phage group I $(P=0.0023)$ and phage complex-80 $(P=0.0066)$. This study confirms that a large number of phage types of $S$. aureus cause bovine mastitis, but that some types predominate. In addition, these findings could indicate that the use of penicillin in the bovine environment has selected for specific types of $S$. aureus in countries with a high frequency of resistance.
\end{abstract}

(C) 2003 Elsevier B.V. All rights reserved.

Keywords: Staphylococcus aureus; Antimicrobial resistance; Phage type

\footnotetext{
* Corresponding author. Tel.: +45-3530-0281; fax: +45-3530-0341.

E-mail address: faa@vetinst.dk (F.M. Aarestrup).
} 


\section{Introduction}

Bovine mastitis is the most common production disease in dairy herds worldwide. It causes significant economic losses due to rejected milk, reduced milk quality, early culling, drug costs, veterinary expenses and increased labour costs for the farmer (Hoblet et al., 1991; Gruet et al., 2001), and it is the most frequent reason for antimicrobial use on dairy farms (Erskine, 2000). The most common cause of bovine mastitis in Denmark and other countries is Staphylococcus aureus (Myllys et al., 1994; Waage et al., 1999). The outcome for treatment of mastitis caused by $S$. aureus is variable and cure rates are not good, primarily due to the poor distribution of the drug in the inflamed udder and the occurrence of antimicrobial resistant staphylococci (Pyörälä and Pyörälä, 1994; Gruet et al., 2001). Penicillins have been the drugs of choice for treatment of bovine mastitis since its introduction in the late 1940s. However, soon after its introduction, penicillin resistant bovine $S$. aureus were recorded and in certain geographical areas the level of penicillin resistance was up to $70 \%$ through the 1960s (Wilson, 1961). An increase in occurrence of penicillin resistance has been observed over time in most countries, but major differences between countries can be observed (Aarestrup and Jensen, 1998). These geographical differences and fluctuations may reflect the occurrence of different clones of $S$. aureus within each country and might be related to the national policy for use of antimicrobial agents.

A large number of different phenotyping and genotyping techniques for characterisation of S. aureus are available (Schlichting et al., 1993; Fitzgerald et al., 1997, 2001; Lange et al., 1999). In previous studies good accordance between different genotyping techniques and phage typing in characterisation of bovine S. aureus has been found (Schlichting et al., 1993; Aarestrup et al., 1995b), and for large scale screening phage typing has previously proved valuable for both human and bovine strains (Larsen et al., 2000; Zadoks et al., 2000).

Several studies have characterised bovine $S$. aureus within countries and identified clustering or clonal relationships between isolates (Lange et al., 1999; Raimundo et al., 1999; Su et al., 2000; Tollersrud et al., 2000; Zadoks et al., 2000; Buzzola et al., 2001) but only a limited number of studies have compared bovine strains from different countries (Kapur et al., 1995; Fitzgerald et al., 1997; De Oliveira et al., 1999).

This study was conducted to investigate the diversity of phage types and associations between penicillin resistance and phage types among $815 \mathrm{~S}$. aureus isolates from bovine mastitis in 10 countries.

\section{Materials and methods}

\subsection{Bacterial isolates}

A total of 815 isolates of $S$. aureus sampled in 10 countries were received at the Danish Veterinary Institute in the beginning of the 1990s. All strains were isolated from independent cases of clinical and subclinical bovine mastitis with only one isolate per herd in the following countries: Denmark (105 isolates), England (100 isolates), Finland (96 isolates), Germany (103 isolates), Iceland (24 isolates), Ireland (42 isolates), Norway (98 isolates), 
Sweden (125 isolates), Switzerland (68 isolates), and USA (56 isolates). It was attempted to obtain isolates that were selected in the same way from all countries, but differences in samples submitted to the diagnostic laboratories must be expected. All isolates were stored at $-80{ }^{\circ} \mathrm{C}$ in Luria Bertani-broth containing $15 \%$ glycerol until testing.

\subsection{Identification of isolates}

All isolates were identified as $S$. aureus upon arrival as previously described (Aarestrup et al., 1995a, 1999).

\subsection{Prior publications using this collection of isolates}

Selected isolates from this collection have previously been used in connection with publications reporting phenotypic and genotypic methods for epidemiological typing of Danish bovine $S$. aureus (Aarestrup et al., 1995b), a study of phage-and ribotype patterns of bovine $S$. aureus from the Nordic countries (Aarestrup et al., 1997), the frequency of alfaand betahaemolysin in Danish bovine and human S. aureus (Aarestrup et al., 1999), the occurrence of blaZ in Danish bovine S. aureus (Vesterholm-Nielsen et al., 1999), antimicrobial susceptibility of bovine $S$. aureus from Europe and USA (De Oliveira et al., 1999), and geographical variation in the presence of staphylococcal enterotoxins (Larsen et al., 2001).

\subsection{Beta-lactamase testing}

All strains were initially tested for penicillin resistance using Oxoid's antimicrobial susceptibility tests discs containing 10 IU penicillin G and were further tested for their ability to produce beta-lactamase enzyme using the beta-lactamase, Diagnostic Tablets, according to the manufacturers guidelines (A/S Rosco, Tåstrup, Denmark).

\subsection{Phage typing}

Strains were phage typed at Statens Serum Institut, Denmark, using the international set of typing phages for human strains according to the method of Blair and Williams (1961). In addition, two Danish experimental phages 89 and 93 (Bülow, 1968; Jessen et al., 1969) were used to differentiate among strains of group III and the 83A-complex. All strains were initially typed at routine test dilution (RTD), though when not typeable, $100 \times$ RTD and $1000 \times$ RTD were applied. The isolates were subdivided into nine phage groups and complexes as follows: 80-complex (80 and/or 81 in combinations with 52 and/or 52A), group I (combinations of 29, 52, 52A, 79, 80), group II (combinations of 3A, 3C, 55, 71), group III (combinations of 6, 42E, 47, 53, 54, 75, 77, (81), 83A, 84, 85, 89, 93), 83A-complex (combinations of 83A, 84, 85, 89, 93), 94,96-complex (combinations of 94,96), type 95, (95), a mixed group, NI (cross combinations of the above mentioned groups/complexes), and a non-typeable group, NT (not typeable at $1000 \times$ RTD) (Parker, 1962, 1983; Renneberg and Rosdahl, 1992). Strains with mixed phage reactions and lytic reactions in combination with phage group II were re-tested. 


\subsection{Minimum inhibitory concentration determinations}

Before minimum inhibitory concentration (MIC) determination was performed, all isolates were revived by subculture on 5\% bovine blood-agar and incubated for $18-24 \mathrm{~h}$ at $35-37^{\circ} \mathrm{C}$. The MIC determinations were performed by a broth micro-dilution method (Sensititre, Westlake, $\mathrm{OH}$ ) in accordance to the manufacturers guidelines and the National Committee for Clinical Laboratory Standards (NCCLS) (NCCLS, 2000). The MIC panels consisted of commercially prepared 96-well microtiter plates (Sensititre) containing the following dehydrated antimicrobial agents (dilution range): avilamycin $(2-32 \mu \mathrm{g} / \mathrm{ml}$ ), bacitracin (16-14 $\mu \mathrm{g} / \mathrm{ml})$, ceftiofur $(0.12-16 \mu \mathrm{g} / \mathrm{ml})$, chloramphenicol $(2-64 \mu \mathrm{g} / \mathrm{ml})$, ciprofloxacin $(0.12-8 \mu \mathrm{g} / \mathrm{ml})$, erythromycin $(0.12-16 \mu \mathrm{g} / \mathrm{ml})$, florfenicol $(1-64 \mu \mathrm{g} / \mathrm{ml})$, gentamicin $(1-32 \mu \mathrm{g} / \mathrm{ml})$, kanamycin $(4-128 \mu \mathrm{g} / \mathrm{ml})$, oxacillin $+2 \%(0.5-8 \mu \mathrm{g} / \mathrm{ml})$, penicillin $(0.06-$ $16 \mu / \mathrm{ml})$, spectinomycin $(8-256 \mu \mathrm{g} / \mathrm{ml})$, streptomycin $(2-128 \mu \mathrm{g} / \mathrm{ml})$, sulphamethoxazole $(8-512 \mu \mathrm{g} / \mathrm{ml})$, quinupristin/dalfopristin $(1-32 \mu \mathrm{g} / \mathrm{ml})$, tetracycline $(0.5-32 \mu \mathrm{g} / \mathrm{ml})$, tiamulin $(0.25-32 \mu \mathrm{g} / \mathrm{ml})$, trimethoprim $(1-32 \mu \mathrm{g} / \mathrm{ml})$, trimethoprim + sulphamethoxazole $(0.25-16 \mu \mathrm{g} / \mathrm{ml})$, vancomycin $(1-32 \mu \mathrm{g} / \mathrm{ml})$, and virginiamycin $(1-32 \mu \mathrm{g} / \mathrm{ml})$. The following quality control strains were included with each batch: $S$. aureus ATCC 29213, Enterococcus faecalis ATCC 29212, Escherichia coli ATCC 25922, and Pseudomonas aeruginosa ATCC 27853 (NCCLS, 2000). All panels were read after incubation at $36^{\circ} \mathrm{C}$ under aerobic conditions within the timeframe of $18-24 \mathrm{~h}$. The first dilution in a row of antibiotic with no visible growth was considered the MIC for each strain. In categorising the MIC-results NCCLS breakpoints (NCCLS, 2000) for resistance were used. For avilamycin, bacitracin, streptomycin and virginiamycin no NCCLS break points are available. For these antimicrobials break points of $\geq 16, \geq 128, \geq 64$ and $\geq 8 \mu \mathrm{g} / \mathrm{ml}$, respectively, were used.

\subsection{Statistical method}

Logistic regression (PROC LOGISTIC, SAS/STAT ${ }^{\circledR}$ Version 8.02, SAS Institute, Cary, USA) was used to determine an association between penicillin resistance and phage groups in 10 countries. Countries were included in the model to correct for unknown country specific contributions. Corrections for over-dispersion using Pearson's goodness-of-fit heterogeneity factor were used. All pairs of phage groups were compared by a statistical test. $P$-values and odds ratio's 95\% confidence limits were given. For the hypothesis tests a significance level of 0.01 was chosen.

\section{Results}

\subsection{Occurrence of resistance among bovine S. aureus}

The distribution of resistance is shown in Table 1. All 815 strains were susceptible to oxacillin, ceftiofur, ciprofloxacin, florfenicol, quinupristin/dalfopristin, tiamulin, trimethoprim + sulphamethoxazole, vancomycin, and virginiamycin. Only 1-2 strains were resistant to each of the following antimicrobials; avilamycin, gentamicin, kanamycin, and 
Table 1

Percentage of resistance among 815 bovine $S$. aureus isolates from 10 countries

\begin{tabular}{|c|c|c|c|c|c|c|c|c|c|c|c|}
\hline$\%$ Resistance & $\begin{array}{l}\text { Denmark } \\
(N=107)\end{array}$ & $\begin{array}{l}\text { Norway } \\
(N=100)\end{array}$ & $\begin{array}{l}\text { Sweden } \\
(N=123)\end{array}$ & $\begin{array}{l}\text { Finland } \\
(N=96)\end{array}$ & $\begin{array}{l}\text { Germany } \\
(N=102) \\
\end{array}$ & $\begin{array}{l}\text { Switzerland } \\
(N=68)\end{array}$ & $\begin{array}{l}\text { Iceland } \\
(N=23)\end{array}$ & $\begin{array}{l}\text { USA } \\
(N=56)\end{array}$ & $\begin{array}{l}\text { England } \\
(N=98)\end{array}$ & $\begin{array}{l}\text { Ireland } \\
(N=42)\end{array}$ & $\begin{array}{l}\text { Total } \\
(N=815)\end{array}$ \\
\hline Bacitracin & 3.7 & 14 & 5.7 & 10.4 & 6.9 & 5.9 & 21.7 & 8.9 & 7.1 & - & 7.7 \\
\hline Chloramphenicol & 0.9 & - & 1.6 & - & 2 & 5.9 & - & 3.6 & 2 & 2.4 & 1.7 \\
\hline Erythromycin & - & 1 & 0.8 & 5.2 & - & 2.9 & - & 1.8 & 2 & - & 1.5 \\
\hline Penicillin & 18.7 & 2 & 28.5 & 29.2 & 24.5 & 32.4 & 34.8 & 50 & 67.3 & 71.4 & 32.4 \\
\hline Spectinomycin & 4.7 & 23 & 29.3 & 1 & 5.9 & 14.7 & - & 3.6 & - & - & 10.2 \\
\hline Streptomycin & 0.9 & 8 & 2.4 & 7.3 & 4.9 & 11.8 & 21.7 & 17.9 & 9.2 & 2.4 & 8.7 \\
\hline Tetracycline & 1.9 & 2 & 0.8 & 13.5 & 2 & 5.9 & 4.3 & 21.4 & 5.1 & 9.5 & 5.6 \\
\hline
\end{tabular}


trimethoprim. Half $(50.1 \%)$ of the strains were susceptible to all 21 antimicrobial agents tested for. Penicillin resistance was found in $32.4 \%$ of all strains and was the most frequent type of resistance observed. A total of $17.5 \%$ of the strains showed resistance to antimicrobial agents other than penicillin.

Bacitracin resistance was found in all countries except for Ireland. The highest frequency of bacitracin resistance was found among strains from Iceland (21.7\%), Norway (14\%), and Finland (10.4\%). Chloramphenicol resistance was not detected in Norway, Finland, or Iceland. The highest occurrence of chloramphenicol resistance was found in strains between Switzerland (5.9\%) and USA (3.6\%). Erythromycin resistance was not detected in Denmark, Germany, Iceland, or Ireland. The highest occurrence was in Finland (5.2\%). Penicillin resistance was found in all countries and showed a remarkable variance between the 10 countries from as low as $2 \%$ among the Norwegian strains up to $71.4 \%$ among the Irish strains. Four countries: Iceland (34.8\%), USA (50\%), England (67.3\%), Ireland $(71.4 \%)$ had penicillin resistance levels above the average of $32.4 \%$. Norway (2\%), Denmark (18.7\%), Sweden (28.5\%), and Finland (29.2\%) together with Germany $(24.5 \%)$ all had penicillin resistance levels below the average of 32.4\%. Spectinomycin resistance was not detected in Iceland, England, or Ireland. The highest occurrence was found in Sweden $(29.3 \%)$, Norway (23\%), and Switzerland (14.7\%). Streptomycin resistance was found in all countries with an average of $8.7 \%$. The highest occurrence of streptomycin resistance was found in Iceland (21.7\%), USA (17.9\%), and Switzerland (11.8\%). Sulphamethoxazole resistance was found in all countries with an average of 3.7 and $73.3 \%$ of the sulphamethoxazole resistant strains were also penicillin resistant. Tetracycline resistance was found in all countries with an average of 5.6\%. The highest occurrence was in the USA $(21.4 \%)$ and Finland $(13.5 \%)$. A total of $82.9 \%$ of the tetracycline resistant strains were also penicillin resistant.

\subsection{Distribution of phage types}

The distribution of strains in the different phage groups and phage complexes are shown in Table 2; only phage types representing four or more strains are shown. A total of 144 different phage types were observed among the 815 strains. However, 111 phage types contained three or less strains. Most strains belonged to the non-typeable group NT (192 isolates), phage group III (187 isolates), phage group I (129 isolates) and phage complex-80 (104 isolates). Together these four phage groups accounted for $75 \%$ of all strains in the study. The remaining $25 \%$ of the strains were distributed among five phage groups and complexes with most strains in the mixed group NI (69 isolates) and in declining order; the 83A-complex (44 isolates), phage group II (40 isolates), the 94,96-complex (26 isolates) and the type 95 (24 isolates) (see also Table 3).

The most common phage types were phage type 29 (86 isolates), phage type 52 (39 isolates), and phage type 80 (38 isolates). The most widely distributed types among the 10 countries were phage types 95 with 24 isolates and 29/52/52A/80 with 18 isolates, each distributed between seven countries. Two phage types, 29 and 83A, were observed in six countries and five phage types, $80,81,52,52 / 52 \mathrm{~A} / 80$, and 77 in five countries. Three phage types, $3 \mathrm{~A}, 89$, and 93 , were found in four countries. The remaining phage types were observed in three countries or less. 
Table 2

Distribution of phage types within 9 phage groups among 10 countries (only phage types representing four or more strains are shown)

\begin{tabular}{|c|c|c|c|c|c|c|c|c|c|c|c|}
\hline Phage group & Phage type & Denmark & Norway & Sweden & Finland & Germany & Switzerland & Iceland & USA & England & Ireland \\
\hline \multirow[t]{4}{*}{ 80-complex } & 80 & 14 & 1 & & 18 & & 4 & & & 1 & \\
\hline & 81 & & & & 3 & & 3 & 1 & 2 & 2 & \\
\hline & 52 & 5 & & 29 & & & 2 & & 2 & 1 & \\
\hline & $52 / 52 \mathrm{~A} / 80$ & 2 & 1 & & & & 4 & & 4 & 3 & \\
\hline \multirow[t]{7}{*}{ Phage group I } & 29 & & 19 & 3 & 17 & 41 & & & 1 & 5 & \\
\hline & $29 / 52$ & 2 & 1 & & & & & & & 4 & \\
\hline & 29/52/52A/80 & 1 & 2 & 2 & & 3 & 7 & & 2 & 1 & \\
\hline & 29/52/52A/80/79 & & & 1 & & 1 & 3 & & & & \\
\hline & $29 / 52 / 52 \mathrm{~A} / 80 / 79 / 81$ & & & & & & 5 & & & & \\
\hline & 79 & & & 2 & 1 & & 1 & & & & \\
\hline & Other group I & & 1 & 3 & & & 1 & & & 1 & \\
\hline \multirow{5}{*}{ Phage group II } & $3 \mathrm{~A}$ & 3 & 1 & 7 & & & & & 3 & & \\
\hline & $3 \mathrm{~A} / 3 \mathrm{C}$ & 2 & & 2 & & 1 & & & & & \\
\hline & $3 \mathrm{~A} / 3 \mathrm{C} / 55 / 71$ & & & & 6 & 2 & & & & & \\
\hline & $3 \mathrm{~A} / 55 / 71$ & & & 3 & & & & & 1 & & \\
\hline & Other group II & 1 & & 2 & 2 & 1 & 1 & & 2 & & \\
\hline \multirow[t]{6}{*}{ Phage group III } & $42 \mathrm{E}$ & 1 & & & 5 & & & & & 8 & \\
\hline & 47 & 11 & & & 1 & & & & 1 & & \\
\hline & 54 & & & & & 1 & & & & 1 & 5 \\
\hline & 75 & 3 & & & & & & & & 1 & \\
\hline & 77 & 2 & & 1 & & 1 & 1 & & & 7 & \\
\hline & Other group III & 14 & 2 & 11 & 23 & 22 & 3 & 5 & 9 & 24 & 23 \\
\hline \multirow[t]{4}{*}{ 83A-complex } & $83 \mathrm{~A}$ & 1 & & 4 & 1 & 1 & & 1 & & 1 & \\
\hline & 89 & & 3 & 9 & & & & 1 & 1 & & \\
\hline & 93 & & & 1 & & 1 & 8 & 1 & & & \\
\hline & Other 83A-complex & 1 & & 3 & 1 & 2 & & & 1 & 2 & \\
\hline \multirow[t]{2}{*}{ 94,96-complex } & 96 & & 8 & & & 6 & & & & & \\
\hline & $94 / 96$ & 4 & & & 1 & 7 & & & & & \\
\hline
\end{tabular}


Table 2 (Continued)

\begin{tabular}{|c|c|c|c|c|c|c|c|c|c|c|c|}
\hline Phage group & Phage type & Denmark & Norway & Sweden & Finland & Germany & Switzerland & Iceland & USA & England & Ireland \\
\hline Type 95 & 95 & 5 & 1 & 13 & 2 & 1 & & 1 & 1 & & \\
\hline \multirow[t]{5}{*}{ Mixed group (NI) } & Gr. I + Gr. II & & & & & & & & & & 14 \\
\hline & Gr. I + 83A & 3 & & & 1 & & & & 1 & 2 & \\
\hline & Gr. I + Gr. III + 95 & 3 & & & & 1 & & & & & \\
\hline & Gr. I + Gr. II + Gr. III + 95 & & & & & & & & 4 & & \\
\hline & Other mixed group & 5 & & 3 & & & 1 & & & 1 & \\
\hline Non-typeable & & 12 & 58 & 26 & 13 & 9 & 14 & 13 & 21 & 29 & \\
\hline
\end{tabular}


Table 3

Distribution of penicillin resistance among different phage groups of $815 \mathrm{~S}$. aureus isolates from bovine mastitis in 10 countries

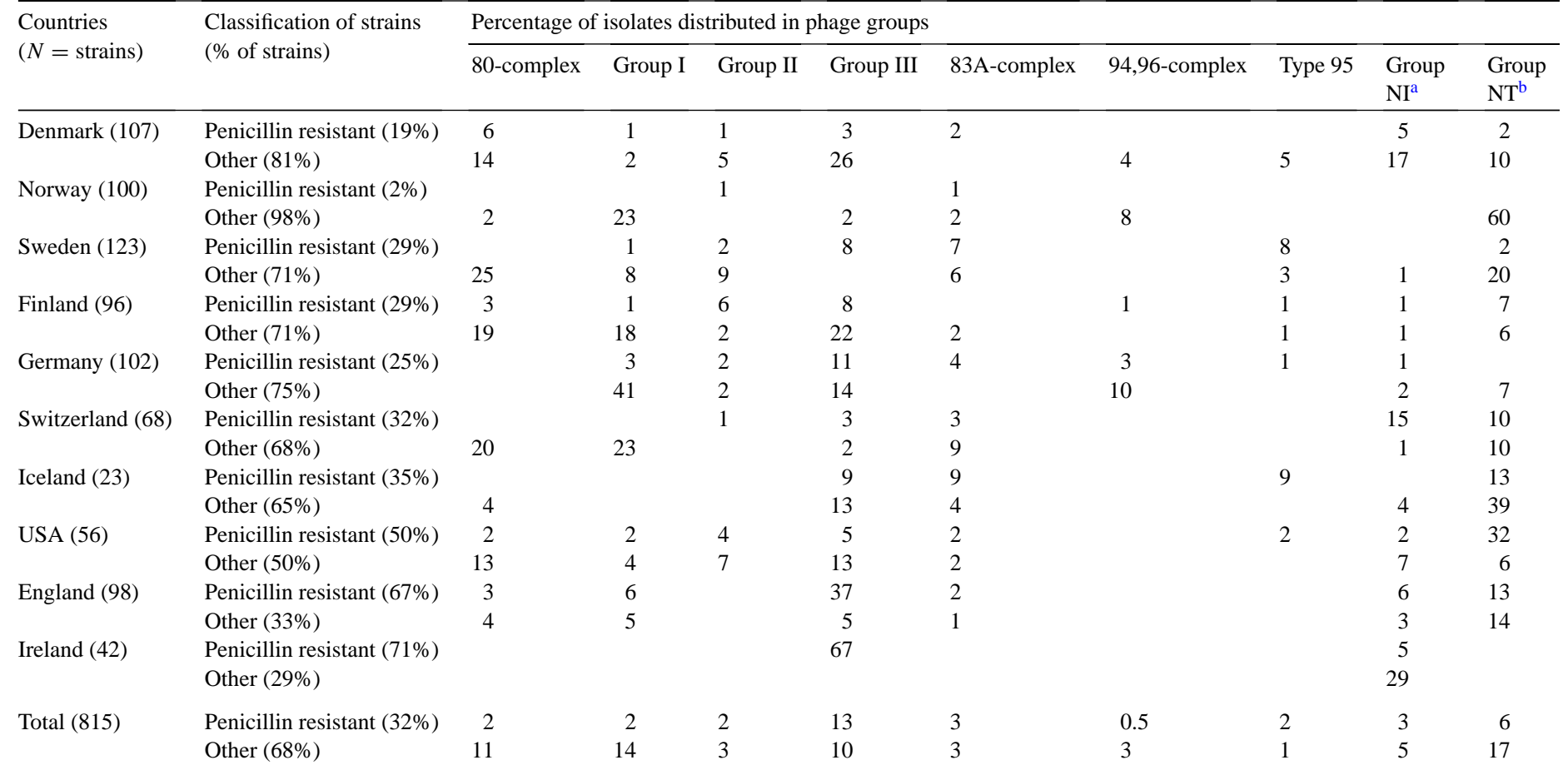

${ }^{a}$ Phage group NI is a mixed group that contains strains lysed with phage types of different phage groups.

${ }^{\mathrm{b}}$ Phage group NT contains non-typeable strains. 
In general, phage types of group I (group I and 80-complex) predominated in all countries, except the USA, England and Ireland where phage types belonging to group III were most common.

The countries showed a different pattern of dominating phage types. Phage type 80 from the 80 -complex was the most common in Denmark and Finland, whereas phage type 52 was in Sweden. Phage type 29, alone or in combination with other phage group I phage types, were present in all countries except for Iceland and Ireland and it was most common in Norway, Finland, and Germany. Group II (type 3A) and type 95 were common in Sweden and the 83A-complex in both Sweden (type 89) and Switzerland (type 93). Phage type 47 was common in Denmark, but only found in low numbers in other countries. Phage type $42 \mathrm{E}$ was common among phage group III isolates from Finland, whereas both phage type $42 \mathrm{E}$ and phage type 77 was common in England. Phage type 96 was common in Norway and both phage type 96 and phage type 94, of the phage complex-94,96, was present in high numbers among strains from Germany. Other countries had low or no occurrence of strains belonging to the phage complex-94,96.

\subsection{Associations between penicillin resistance and phage types}

In the phage complex-80, $85 \%$ of the penicillin resistant strains were of phage type 52 or 81. Phage type 80 seemed to be less related to penicillin resistance compared to the other phage types within the 80 -complex. In phage group I, $85 \%$ of the penicillin resistant strains were of phage type 29 or 29/52. In phage group II, nine different phage types were associated with penicillin resistance, however $31 \%$ of the strains were of phage type $3 \mathrm{~A} / 3 \mathrm{C} / 55 / 71$. In phage group III, 109 strains and 49 phage types were associated with penicillin resistance. England and Ireland contributed $62 \%$ of these strains and 21 phage types. The most common phage type associated with penicillin resistance, alone or in combinations with others in phage group III (regardless of the national occurrence of penicillin resistance) was phage type $42 \mathrm{E}$ that was found on $60 \%$ of the strains. The second and third most common lytic reaction was phage type 47 and 54 . In the $83 \mathrm{~A}$-complex, $30 \%$ of the penicillin resistant strains were phage type $83 \mathrm{~A}$ and $22 \%$ were phage type 93 . In the 94,96-complex, all penicillin resistant strains were of phage type 94,96. In the mixed group (NI) the strains carrying penicillin resistance typically had combinations of phage types related to penicillin resistance in other phage groups.

\subsection{Associations between penicillin resistance and phage groups}

The distribution of penicillin resistance among phage groups in 10 countries is shown in Table 3. A general association between phage groups and penicillin resistance was observed in all countries.

The 80-complex and phage group I together with the phage complex-94,96 and the mixed group (NI) were not associated to penicillin resistance, whereas phage group III, the 83A-complex, and type 95, were significantly associated with penicillin resistance $(P<$ 0.01 ). When compared to the phage complex- 80 the significance level in the following phage groups was: phage group III $(P=0.0066, \mathrm{OR}=0.1506, \mathrm{CI} 95 \%=0.0385-0.5900)$, the 83A-complex $(P=0.0098, \mathrm{OR}=0.1037, \mathrm{CI} 95 \%=0.0186-0.5792)$, and the type 
$95(P=0.0069$, OR $=0.0592$, CI $95 \%=0.0076-0.4607)$. When compared to the phage group I the significance level in the following phage groups was: phage group III $(P=0.0023$, OR $=0.1219$, CI 95\% $=0.0315-0.4722)$, the 83A-complex $(P=0.0055$, $\mathrm{OR}=0.0839, \mathrm{CI} 95 \%=0.0146-0.4830)$, the type $95(P=0.0046, \mathrm{OR}=0.0479, \mathrm{CI}$ $95 \%=0.0059-0.3924)$, and phage group NT $(P=0.0089, \mathrm{OR}=0.2176, \mathrm{CI} 95 \%=$ 0.0694-0.6823).

Phage group II showed an association with penicillin resistance within a $P<0.05$ significance level in contrast to the phage complex- 80 and phage group I, but did not meet the defined significance criteria of $P<0.01$ and the CI $95 \%$ limits were very wide.

When comparing the countries with the lowest (Norway and Denmark) and the highest (England and Ireland) occurrences of penicillin resistance it was observed that (1) penicillin resistance was related to phage group III, and (2) that the diversity of phage groups was diminished in England and Ireland.

\section{Discussion}

The present study was conducted to investigate the association between antimicrobial resistance and phage types in an international collection of bovine $S$. aureus isolated from cases of clinical and subclinical mastitis.

Several studies worldwide have reported susceptibility to antimicrobial agents in $S$. aureus from bovine mastitis. In most of these studies, a frequent occurrence of penicillin resistance has been found, while there has only been a limited occurrence of resistance to other antimicrobial agents (Werckenthin et al., 2001). This was also confirmed in the present study. Major differences in the occurrence of penicillin resistance have also been observed between countries (Aarestrup and Jensen, 1998). Thus, previous reports have, as also observed in this study, found very high frequencies of penicillin resistance in the USA, England and Ireland, whereas the occurrence of penicillin resistance in the Scandinavian countries (Denmark, Norway and Sweden) is low (Aarestrup and Jensen, 1998). This difference may be attributed to the differences in the antimicrobial policy in these countries. In general it is believed that the Scandinavian countries have a more restrictive antimicrobial policy compared to most other countries. The remaining European countries investigated in this study (Germany, Switzerland, Iceland, Finland) had intermediate levels of penicillin resistance as also observed in previous studies (Aarestrup and Jensen, 1998).

Phage typing has previously been used in several investigations of the epidemiology of $S$. aureus mastitis (Davidson, 1961; Fox et al., 1991) and a high typeability has in general been reported in most studies (Swartz et al., 1985; Mackie et al., 1987; Fox et al., 1991; Aarestrup et al., 1997). In the present study a relatively high typeability was observed among isolates (76\%), though a large number of phage group NT were found in Norway and the USA (Table 3).

In general, the majority of bovine isolates are lysed by phages belonging to phage group I and III (Frost, 1967; Davidson, 1972; Holmberg, 1975; Swartz et al., 1985; Mackie et al., 1987). This correlates with the findings in this study. However, some studies have found domination of phage group II (Thorne and Hallander, 1970; Younis et al., 2000) and high levels of a mixed group (NI) (Adesiyun, 1994), together with presence of phage group III 
isolates. In this study $5 \%$ of the strains belonged to phage group II and $8.5 \%$ belonged to the mixed group.

In the present study it was observed that a large number of types can cause bovine mastitis but also that some predominant types were restricted to a single or a few countries only while other types were found in several different geographic regions. In other studies on characterisation of bovine $S$. aureus patterns of geographical enclosed clones similar observations have also been done (Matthews et al., 1994; Aarestrup et al., 1995b; Kapur et al., 1995; Pantucek et al., 1996; Fitzgerald et al., 1997; Lange et al., 1999; Raimundo et al., 1999; Su et al., 2000; Zadoks et al., 2000; Buzzola et al., 2001) suggesting that a few specialised clones of $S$. aureus are responsible for the majority of cases of bovine mastitis and that these clones have a broad geographic distribution. Thus, previous and the present study show that a limited number of clones are responsible for the majority of cases of bovine mastitis. Some of these clones have a broad geographic distribution, while others are restricted to individual countries or regions.

In the present study a strong association between phage types and resistance to penicillin was observed among strains from all countries. Thus, phage types, within phage group I, were mostly susceptible to penicillin while there was a high frequency of resistant strains within phage group III. Phage group I was common in countries with a low frequency of resistance. Thus, if it is assumed that the use of penicillin is the major selection force for penicillin resistance then this would imply that the use of penicillin has selected for penicillin resistant variants of $S$. aureus in countries such as England, the USA and Ireland, whereas the original susceptible variants still are common in countries with a low occurrence of resistance like Denmark and Norway. In contrast it could also be that management or other factors have selected for certain phage types that happened to be penicillin resistant. Thus, that selection for resistance has nothing to do with usage of penicillin. An indication that the first assumption might be true can be found in the fact that the occurrence of penicillin resistance within isolates of phage group I also was higher among isolates from England compared to countries with a low frequency of penicillin resistance. Resistance to penicillin has also previously been found associated with phage group III among a limited number of bovine $S$. aureus isolates from South African dairy herds (Giesecke et al., 1972; Swartz et al., 1985).

Another indication that penicillin has influenced the diversity of the natural population of bovine $S$. aureus is the lack of isolates in phage group II and phage complex-94,96 found in countries with an occurrence of penicillin resistance above average in the present study. These two phage groups have been found to harbour phage group specificity determined by phage restriction and phage modification systems making it difficult for them to adopt foreign DNA (Asheshov et al., 1977; Parker, 1983; Van Boven, 1974). In a selective environment these groups will therefore probably have a growth disadvantage.

Among human isolates of $S$. aureus associations between changes in phage patterns and development of penicillin resistance has been observed (Parker, 1983; Rosdahl et al., 2000). In a study on 276 S. aureus isolates from 1927 to 1947, before usage of penicillin became widespread, this distribution of phage types and groups were found: (group I (32\%), 80-complex (22.1\%), group II (21.6\%), group III (8.8\%), group IV (phage type 42D) $(4.6 \%)$, type $187(2.6 \%)$, mixed group (7.7\%) and non-typeable (29.7\%)) (Blair and Carr, 1960). The same distribution of phage types was also found in another study in 1945 on 1340 isolates (Wilson and Atkinson, 1945). During the 1960s, penicillin resistant S. aureus isolated from 
humans were dominated by the phage complex-52/52A/80/81. These were later replaced by the more multi-resistant phage group III and 83A-complex, but since the end of the 1970s most human strains (80-90\%) have been penicillin resistant, due to production of beta-lactamase, without belonging to a dominating phage group or complex (Parker, 1983; Renneberg and Rosdahl, 1992). In a Danish survey of human S. aureus from hospital infections during 1977-1990 it was shown that penicillin resistance increased from 78.7 to $85.5 \%$. The change in phage type pattern showed that the increase was caused by the introduction and spread of many resistant strains of type 95 and the 94,96-complex, and an increased occurrence of resistant strains of phage group II (Renneberg and Rosdahl, 1992). These results could suggest that the strains infecting the bovine udder are undergoing similar changes in the distribution of types, probably also influenced by selective pressures through the use of penicillin and other drugs.

\section{Conclusion}

In conclusion, this study showed that a large number of type of $S$. aureus can cause bovine mastitis, but that some types predominate. Penicillin resistance is widespread among $S$. aureus from bovine mastitis, but resistance to other antimicrobial agents is limited, and an association between phage group III and penicillin resistance was observed. These findings could suggest that the use of penicillin in the bovine environment has selected for specific types of $S$. aureus in countries with a high frequency of resistance.

\section{Acknowledgements}

This work was supported by the Danish Veterinary Institute, the Royal Veterinary and Agricultural University, Denmark, and the Danish Dairy Board. Technical staffing in section for antimicrobial resistance and environmental microbiology at the Danish Veterinary Institute are thanked for technical assistance on MIC determinations and Jette Olsen, Statens Serum Institut, are thanked for technical assistance on phage typing.

\section{References}

Aarestrup, F.M., Jensen, N.E., 1998. Development of penicillin resistance among Staphylococcus aureus isolated from bovine mastitis in Denmark and other countries. Microb. Drug Resist. 4, 247-256.

Aarestrup, F.M., Wegener, H.C., Rosdahl, V.T., Jensen, N.E., 1995a. Staphylococcal and other bacterial species associated with intramammary infections in Danish dairy herds. Acta Vet. Scand. 36, 475-487.

Aarestrup, F.M., Wegener, H.C., Rosdahl, V.T., 1995b. Evaluation of phenotypic and genotypic methods for epidemiological typing of Staphylococcus aureus isolates from bovine mastitis in Denmark. Vet. Microbiol. 45, 139-150.

Aarestrup, F.M., Wegener, H.C., Jensen, N.E., Jonsson, O., Myllys, V., Thorberg, B.M., et al., 1997. A study of phage- and ribotype patterns of Staphylococcus aureus isolated from bovine mastitis in the Nordic countries. Acta Vet. Scand. 38, 243-252.

Aarestrup, F.M., Larsen, H.D., Eriksen, N.H.R., Elsberg, C., Jensen, N.E., 1999. Frequency of alfa- and betahaemolysin in Staphylococcus aureus of bovine and human origin. APMIS 107, 425-430. 
Adesiyun, A.A., 1994. Characteristics of Staphylococcus aureus strains isolated from bovine mastitic milk: bacteriophage and antimicrobial agent susceptibility, and enterotoxigenicity. J. Vet. Med. B 42, 129-139.

Asheshov, E.H., Coe, A.W., Porthouse, A., 1977. Properties of strains of Staphylococcus aureus in the 94,96-complex. J. Med. Microbiol. 10, 171-178.

Blair, J.E., Carr, M., 1960. Distribution of phage groups of Staphylococcus aureus in the years 1927 through 1947. Science 132, 1247-1248.

Blair, J.E., Williams, R.E.O., 1961. Phage typing of staphylococci. Bull. World Health Org. 24, 771-784.

Bülow, P., 1968. A new epidemic phage type of Staphylococcus aureus. 1. The experimental typing phage 6557. APMIS 72, 147-159.

Buzzola, F.R., Quelle, L., Gomez, M.I., Catalano, M., Steele-Moore, L., Berg, D., et al., 2001. Genotypic analysis of Staphylococcus aureus from milk of dairy cows with mastitis in Argentina. Epidemiol. Infect. 126, 445-452.

Davidson, I., 1961. Observations on the pathogenic staphylococci in a dairy herd during a period of six years. Res. Vet. Sci. 2, 22-40.

Davidson, I., 1972. A collaborative investigation of phages for typing bovine staphylococci. Bull. World Health Org. 46, 81-98.

De Oliveira, A.P., Watts, J.L., Salmon, S.A., Aarestrup, F.M., 1999. Antimicrobial susceptibility of Staphylococcus aureus isolated from bovine mastitis in Europe and the United States. J. Dairy Sci. 83, 855-862.

Erskine, R.J., 2000. Antimicrobial drug use in bovine mastitis. In: Prescott, J.F., Baggot, J.D., Walker, R.D. (Eds.), Antimicrobial Therapy in Veterinary Medicine. Iowa State University Press, pp. 712-734.

Fitzgerald, J.R., Meaney, W.J., Hartigan, P.J., Smyth, C.J., Kapur, V., 1997. Fine-structure molecular epidemiological analysis of Staphylococcus aureus recovered from cows. Epidemiol. Infect. 119, 261-269.

Fitzgerald, J.R., Sturdevant, D.E., Mackie, S.M., Gill, S.R., Musser, J.M., 2001. Evolutionary genomics of Staphylococcus aureus: insight into the origin of methicillin-resistant strains and the toxic shock syndrome epidemic. PNAS 98, 8821-8826.

Fox, L.K., Gershman, M., Hanock, D.D., Hutton, C.T., 1991. Fomites and reservoirs of Staphylococcus aureus causing intramammary infections as determined by phage typing: the effect of milking time hygiene practices. Cornell Vet. 81, 183-193.

Frost, A.J., 1967. Phage typing of Staphylococcus aureus from dairy cattle in Australia. J. Hyg. Camb. 65, 311-319.

Giesecke, W.H., Van Den Heever, L.W., Du Toit, I.J., 1972. Staphylococcal mastitis: phage types and patterns of Staphylococcus aureus. J. Vet. Res. 39, 87-96.

Gruet, P., Maincent, P., Berthelot, X., Kaltsatos, V., 2001. Bovine mastitis and intramammary drug delivery: review and perspectives. Adv. Drug Delivery Rev. 50, 245-259.

Hoblet, K.H., Schnitkey, G.D., Arbaugh, D., Hogan, J.S., Smith, K.L., Schoenberger, P.S., et al., 1991. Costs associated with selected preventive practices and with episodes of clinical mastitis in nine herds with low somatic cell counts. JAVMA 199, 190-196.

Holmberg, O., 1975. Phage typing of Staphylococcus aureus strains isolated in Sweden from bovine milk. Acta Vet. Scand. 16, 411-419.

Jessen, O., Rosendal, K., Bülow, P., Faber, V., Eriksen, K.R., 1969. Changing staphylococci and staphylococcal infections. A ten year study of bacteria and cases of bacteremia. N. Engl. J. Med. 281, 627-635.

Kapur, V., Sischo, W.M., Greer, R.S., Whittam, T.S., Musser, J.M., 1995. Molecular population genetic analysis of Staphylococcus aureus recovered from cows. J. Clin. Microbiol. 33, 376-380.

Lange, C., Cardoso, M., Senczek, D., Schwarz, S., 1999. Molecular subtyping of Staphylococcus aureus isolates from cases of bovine mastitis in Brazil. Vet. Microbiol. 67, 127-141.

Larsen, H.D., Sloth, K.H., Elsberg, C., Enevoldsen, C., Pedersen, L.H., Eriksen, N.H.R., et al., 2000. The dynamics of Staphylococcus aureus intramammary infection in nine Danish dairy herds. Vet. Microbiol. 71, 89-101.

Larsen, H.D., Aarestrup, F.M., Jensen, N.E., 2001. Geographical variation in the presence of genes encoding superantigenic exotoxins and beta-hemolysin among Staphylococcus aureus isolated from bovine mastitis in Europe and USA. Vet. Microbiol. 2258, 1-7.

Mackie, D.P., Pollock, D.A., Rodgers, S.P., Logan, E.F., 1987. Phage typing of Staphylococcus aureus associated with subclinical bovine mastitis. J. Dairy Res. 54, 1-5.

Matthews, K.R., Kumar, S.J., O’Conner, S.A., Harmon, R.J., Pankey, J.W., Fox, L.K., Oliver, S.P., 1994. Genomic fingerprints of Staphylococcus aureus of bovine origin by polymerase chain reaction-based DNA fingerprinting. Epidemiol. Infect. 112, 177-186. 
Myllys, V., Honkanen, B.T., Huovinen, P., Sandholm, M., Nurmi, E., 1994. Association of changes in the bacterial ecology of bovine mastitis with changes in the use of milking machines and antibacterial drugs. Acta Vet. Scand. 35, 363-369.

NCCLS, 2000. Methods for dilution antimicrobial susceptibility tests for bacteria that grow aerobically, NCCLS M7-A5.

Pantucek, R., Gotz, F., Doskar, J., Rosypal, S., 1996. Genomic variability of Staphylococcus aureus and the other coagulase-positive staphylococcus species estimated by macrorestriction analysis using pulsed-field gel electrophoresis. Int. J. Syst. Bacteriol. 46, 216-222.

Parker, M.T., 1962. Phage typing and the epidemiology of Staphylococcus aureus infection 57. J. Appl. Bacteriol. 25, 385-402.

Parker, M.T., 1983. The significance of phage typing in Staphylococcus aureus 58. In: Eastmore, C.F.S., Adlam, C. (Eds.), Staphylococci and Staphylococcal Infections. Academic Press, London, pp. 33-62.

Pyörälä, S.H.K., Pyörälä, E.O., 1994. Efficacy of bovine clinical mastitis therapy during lactation. In: Proceedings of the XVII Nordic Veterinary Congress, Reykjavik, Iceland, July 26-29.

Raimundo, O., Deighton, M., Capstick, J., Gerraty, N., 1999. Molecular typing of Staphylococcus aureus of bovine origin by polymorphisms of the coagulase gene. Vet. Microbiol. 66, 275-284.

Renneberg, J., Rosdahl, V.T., 1992. Epidemiological studies of penicillin resistance in Danish Staphylococcus aureus strains in the period 1977-1990. Scand. J. Infect. Dis. 24, 401-409.

Rosdahl, V.T., Espersen, F., Frimodt-Møller, N., Skinhøj, P., 2000. Changing Staphylococcus aureus Epidemiology: 30 Years Experience. ISSSI, Kolding, Denmark.

Schlichting, C., Branger, C., Fournier, J.M., Witte, W., Boutonnier, A., Wolz, C., et al., 1993. Typing of Staphylococcus aureus by pulse-field gel electrophoresis, zymotyping, capsular typing, and phage typing: resolution of clonal relationships. J. Clin. Microbiol. 31, 227-232.

Su, C., Kanevsky, I., Jayarao, B.M., Sordillo, L.M., 2000. Phylogenetic relationships of Staphylococcus aureus from bovine mastitis based on coagulase gene polymorphism. Vet. Microbiol. 71, 53-58.

Swartz, R., Jooste, P.J., Novello, J.C., 1985. Bacteriophage typing of Staphylococcus aureus strains isolated from Bloemfontein dairy herds. J. S. Afr. Vet. Assoc. 56, 69-73.

Thorne, H., Hallander, H.O., 1970. Phage typing of Staphylococcus aureus from bovine mastitis. APMIS 78, $425-428$.

Tollersrud, T., Kenny, K., Caugant, D.A., Lund, A., 2000. Characterisation of isolates of Staphylococcus aureus from acute, chronic, and subclinical mastitis in cows in Norway. APMIS 108, 565-572.

Van Boven, C.P., 1974. Restriction and modification of phages in staphylococcal phage typing. Ann. NY Acad. Sci. 236, 376-388.

Vesterholm-Nielsen, M., Ølholm Larsen, M., Olsen, J.E., Aarestrup, F.M., 1999. Occurrence of the blaZ Gene in penicillin resistant Staphylococcus aureus isolated from bovine mastitis in Denmark. Acta Vet. Scand. 40, 279-286.

Waage, S., Mork, T., Roros, A., Aasland, D., Hunshamar, A., Odegaard, S.A., 1999. Bacteria associated with clinical mastitis in dairy heifers. J. Dairy Sci. 82, 712-719.

Werckenthin, C., Cardoso, M., Martel, J.-L., Schwarz, S., 2001. Antimicrobial resistance in staphylococci from animals with particular reference to bovine Staphylococcus aureus, porcine Staphylococcus hyicus, and canine Staphylococcus intermedius. Vet. Res. 32, 341-362.

Wilson, C.D., 1961. The treatment of staphylococcal mastitis. Vet. Res. 73, 1019-1024.

Wilson, G.S., Atkinson, J.D., 1945. Typing of staphylococci by the bacteriophage method. The Lancet 1, 647-648.

Younis, A., Leitner, G., Heller, D.E., Samra, Z., Gadba, R., Lubashevsky, G., et al., 2000. Phenotypic characteristics of Staphylococcus aureus isolated from bovine mastitis in Israeli dairy herds. J. Vet. Med. B 47, 591-597.

Zadoks, R., Van Leeuwen, W., Barkema, H., Sampimon, O., Verbrugh, H., Schukken, Y.H., Van Belkum, A., 2000. Application of pulsed-field gel electrophoresis and binary typing as tools in veterinary clinical microbiology and molecular epidemiologic analysis of bovine and human Staphylococcus aureus isolates. J. Clin. Microbiol. 38, 1931-1939. 